\title{
An accident right before the finish of the first stage of the 77th edition of the Tour de Pologne - Legal characterisation of the accident through the prism of criminal law
}

Authors' Contribution: A Study Design B Data Collection C Statistical Analysis D Data Interpretation E Manuscript Preparation F Literature Search G Funds Collection

\author{
Cezary Waldziński ${ }^{\text {ABCDEFG }}$, Aleksandra Durzyńska ${ }^{1 \text { ABCDEFG, }}$ Tomasz Waldziński ${ }^{1 \text { ABCDEFG, }}$ \\ Kazimierz Kochanowicz 2 ABCDEFG \\ ${ }^{1}$ Lomza State University of Applied Sciences, Lomza, Poland \\ 2 Department of Theory of Sport and Human Motricity, Faculty of Physical Culture, \\ Gdansk University of Physical Education and Sport, Gdansk, Poland
}

On August 5, 2020 the first of five stages of the 77th edition of the Tour de Pologne took place. In the final meters of the first stage of the race around Poland, an unfortunate accident occurred. JumboVisma rider, Dylan Groenewegen, who fought for the victory, deviated from his line and by going to the right prevented Fabio Jakobsen from riding and finishing the race. As a result, the Deceuninck-QuickStep cyclist hit the barriers at high speed and suffered very serious injuries. Fabio Jakobsen, a talented cyclist, was taken to hospital in a severe condition. One of the judges who stood nearby and handled the photocell as well as numerous cyclists from the peloton were also seriously injured. By the commissaires' panel decision Dylan Groenewegen was disqualified and excluded from further competition. The Union Cycliste Internationale considered the cyclist's behaviour unacceptable and referred the matter to the Disciplinary Commission, to request the imposition of sanctions commensurate with the seriousness of the facts. It will be extremely difficult to determine that the injuries suffered by Fabio Jakobsen in the crash at the finish of the first stage of the 77th Tour de Pologne were caused under the conditions of sport risk justification.

Key words: criminal law, accident, Tour de Pologne.

\section{article details}

Article statistics:

Full-text PDF:

Copyright

Indexation:

Funding:

Conflict of interests:

Corresponding author:

Open Access License:

Word count: 2,153; Tables: 0; Figures: 0; References: 17

Received: October 2020; Accepted: March 2021; Published: September 2021

http://www.balticsportscience.com

(c) Gdansk University of Physical Education and Sport, Poland

Celdes, Clarivate Analytics Emerging Sources Citation Index (ESCI), CNKI Scholar (China National Knowledge Infrastructure), CNPIEC, DOAJ, EBSCO - Central \& Eastern European Academic Source, EBSCO - SPORTDiscus, EBSCO Discovery Service, Google Scholar, Index Copernicus, J-Gate, Naviga (Softweco, Primo Central (ExLibris), ProQuest - Family Health, ProQuest - Health \& Medical Complete, ProQuest - Illustrata: Health Sciences, ProQuest Nursing \& Allied Health Source, Summon (Serials Solutions/ProQuest, TDOne (TDNet), Ulrich's Periodicals Directory/ ulrichsweb, WorldCat (OCLC)

This research received no specific grant from any funding agency in the public, commercial, or not-for-profit sectors. Authors have declared that no competing interest exists.

Aleksandra Durzyńska, Spółdzielcza Str. 29/16, 18-400 Łomża, Poland; phone +48 668426659, e-mail: adurzynska@ pwsip.edu.pl

This is an open access article distributed under the terms of the Creative Commons Attribution-Non-Commercial-NoDerivatives 4.0 International (https://creativecommons.org/licenses/by-nc-nd/4.0/), which permits use, distribution and reproduction in any medium, provided the original work is properly cited, the use is non-commercial and is otherwise in compliance with the license. 


\section{INTRODUCTION}

The 2020 Tour de Pologne was expected to be unique as it was the first stage race after the break caused by the coronavirus - SARS-CoV-2. However, the 77th edition of Tour de Pologne is famous for other reasons. At the finish of the first stage of this race an unfortunate accident happened. Fabio Jakobsen, a talented cyclist of the DeceuninckQuick-Step team, suffered serious injuries.

Shortly after the accident, the Regional Public Prosecutor's Office in Katowice initiated a principal investigation in order to determine the circumstances of the crash and assess whether a crime has been committed. According to the statement of the Regional Public Prosecutor's Office in Katowice, due to the nature of injuries suffered by the cyclist and the judge, the investigation is conducted in the matter of unintentionally inflicting grievous bodily harm, i.e. an act under article $156 \S 2$ of the Criminal Code [1, 2]. The prosecutor must, therefore, determine whether the caused injuries were a result of culpable human activity or whether they were a result of a combination of several circumstances, and thus neither fault nor the criminal liability can be attributed to a person.

This article attempts to assess the unfortunate accident that occurred just before the finish line of the first stage of the 2020 Tour de Pologne through the prism of the provisions of the Act of 6 June 1997, Criminal Code [3], including the so-called (binding in Poland) sport risk justification, which excludes the criminal liability of the competitor who caused damage to the health or death of the competitor or third parties (bystanders) during the competition. There is no room for doubt: the prosecutor conducting the investigation in the matter of unintentionally inflicting grievous bodily harm, after gathering all evidence, will have to answer the question whether the behaviour of Dylan Groenewegen, a cyclist, falls within the sport risk justification of the crime.

\section{COURSE OF EVENTS REPRODUCED ON THE BASIS OF COMMONLY AVAILABLE MATERIALS}

First of all, it should be noted that this accident was recorded on more than one device and these recordings are widely available on the Internet [4]. Thus, such material is objective in character. It is resistant to the passage of time and is not prone to deformation. As a consequence, recreating the course of this particular crash is not difficult.

On August 5, 2020, the first of five stages of the 77th edition of the Tour de Pologne took place. Cyclists started this stage at the Silesian Stadium in Chorzów, a multifunctional sport stadium in Silesian Voivodeship, and finished next to the Spodek Arena in Katowice. They rode for $196 \mathrm{~km}$.

In the final meters of the first stage of the race around Poland, an unfortunate accident occurred. Jumbo-Visma cyclist, Dylan Groenewegen, who fought for the victory, deviated from his line and by going to the right prevented Fabio Jakobsen from cycling and finishing the race. As a result, the Deceuninck-Quick-Step cyclist hit the barriers at high speed and suffered very serious injuries. Fabio Jakobsen, a talented cyclist, was taken to hospital in a severe condition. One of the judges, who stood nearby and handled the photocell, and numerous cyclists from the peloton were also seriously injured. All injured were given immediate medical assistance. Those most severely affected were sent to the Vovoidship Specialist Hospital in Sosnowiec, where they received further medical assistance. Dutch cyclist Fabio Jakobsen suffered the most serious injuries. He underwent a surgery and now has to go through a long rehabilitation process [5-9].

By the commissaires' panel decision, Dylan Groenewegen was disqualified and excluded from further competition. The Union Cycliste Internationale considered the cyclist's 
behaviour unacceptable and referred the matter to the Disciplinary Commission to request the imposition of sanctions commensurate with the seriousness of the facts [10].

\section{LEGAL ANALYSIS OF THE CRASH THROUGH THE PRISM OF THE POLISH CRIMINAL CODE}

The analysed event occurred in the territory of the Republic of Poland. As a consequence, in accordance with the territoriality principle stated in Article 5 of the Polish Criminal Code, the unfortunate accident should be assessed through the prism of the Polish criminal code. Article 5 of the Polish Criminal Code applies to a perpetrator regardless of his nationality, thus the Polish criminal code applies to Polish citizens (regardless of the place of domicile) and to foreigners.

Polish criminal law sets out circumstances which exclude criminal liability. Such circumstances include, among others, the so-called justifications. It is generally accepted in the legal doctrine that justification is a circumstance excluding unlawfulness and thus criminal liability. Criminal law identifies statutory and non-statutory justifications. The former are listed in the statute, where their features are defined (e.g., right to selfdefence, state of higher necessity). On the other hand, non-statutory justifications do not have their own statutory source, but they have been developed in legal doctrine and are recognised in judicial decisions.

Sport risk is one of the so-called non-statutory justifications, i.e. circumstances excluding the unlawfulness of a prohibited act. Although actions of a competitor acting under the conditions of sport risk justification formally fulfil the elements of a crime (e.g. causing serious injury to another competitor), yet there are not illegal and, therefore, do not constitute a crime.

Before giving grounds applying to the sport risk justification, it is necessary to make a few general remarks about the investigation being conducted in the Regional Public Prosecutor's Office in Katowice, as well as the direction in which it is being conducted. What is important, the investigation is being carried as an ad rem procedure, so no one has been charged with inflicting grievous bodily harm yet. According to the statement of the Regional Prosecutor's Office in Katowice, due to the nature of injuries suffered, the investigation is conducted in the matter of unintentionally inflicting grievous bodily harm, i.e. an act under article $156 \S 2$ of the Criminal Code. Pursuant to article $9 \S 2$ of the Criminal Code, a prohibited act is committed unintentionally if the perpetrator, without having an intent of its commission, commits it due to non-compliance with carefulness required in the given circumstances, although he has foreseen or might have foreseen the possibility of committing it. In the event in question, the source of the precautionary rules were the rules of road bicycle racing, in particular the precautionary rules for the prevention of acts of violence and sports accidents, not the traffic rules or the speed limits.

The unfortunate accident could not be classified as a crime against traffic safety, i.e. the so-called "serious traffic accident", as set out in article $177 \S 2$ of the Criminal Code, which is subject to the penalty of deprivation of liberty for between 6 months and 8 years. A traffic accident, defined in article 177 \$2 of the Criminal Code, may be a result of violation of road safety rules. However, the national road safety rules did not apply to the cyclists - they cycled on a road closed for traffic.

Therefore, the cyclists were not road traffic participants. The road was reserved for competitors only. For this reason, the competitors were not obliged to follow the traffic rules, including the speed limits. However, what is important, cyclists were obliged to follow the rules of their sport discipline - road bicycle racing. For these reasons, the Prosecutor's Office's viewpoint on the legal characterisation of the act is adequate. 
As stated above, the prosecutor in charge of the investigation, after gathering all evidence, will have to answer the question whether the behaviour of cyclist Dylan Groenewegen falls within the sport risk justification. In the Polish legal system, the exclusion of criminal liability of a competitor on the basis of the sport risk justification for injury or death of an opponent takes place when the following conditions are jointly met [11]:

1. death or injury occurred while practicing the permitted sport,

2. the action was taken for a specific sport purpose, i.e. in order to defeat another player or team,

3. the perpetrator of death or injury followed the rules applicable in the given sport discipline.

Legal literature and judicial decisions indicate that the exclusion of criminal liability for causing a sport accident under the conditions of a sport risk justification may occur not only when the competitor is involved in the accident, i.e. both the injured party and the perpetrator is the competitor, but also when the effects of the participant's behaviour affect third parties (bystanders), i.e. audience, judges, coaches, etc. [12, 13].

According to article 13 section 1 point 2 of the act on sport [14], Polish sports associations have the exclusive right to establish and implement sports, organisational and disciplinary rules in sports competition organised by them. Sport rules take a central place in the assessment of a competitor's criminal liability for the death or injury of a fellow competitor. However, not every violation of sport rules will result in criminal liability. Such liability occurs only if there is a causal relationship between the violation of a specific rule and the result - death or bodily injury of a competitor. In other words, causing the effect of death or bodily injury of a competitor can only be attributed to another competitor if the compliance with the sports rules would prevent this effect from occurring.

Sports rules are based on the standard of conduct addressed to specific groups, distinguished due to the nature of sports activities, i.e. both to game participants, referees, coaches or organizers of sports events [15]. These principles can perform various functions, and therefore science uses different typologies. Szwarc [16] distinguishes between an order principle and a precautionary principle. The order principle defines the course of a fight or game, while the precautionary principle is used to prevent brutality and sports accidents. Only the precautionary principle is of criminal law significance, as it may form the basis for a legal assessment of an athlete's behaviour. On the other hand, violation of the order principle may only result in liability in the course of the game (in-sport). In addition, Szwarc [16] distinguishes among the above-mentioned rules of sports fundamental (important) rules, which are essential for a given branch of sport and the violation of which means that a given behaviour ceases to be considered a sport, and any accidents caused in connection with it should be assessed through the prism of the legal criminal norm [16].

The sport rules established by the Polish Cycling Federation are a consequence of the Union Cycliste Internationale regulations. The sports provisions of the Polish Cycling Federation are systematically and directly translated from the original regulations of the Union Cycliste Internationale [17]. In accordance with point 2.3.036 of Part II entitled "Road Races" of the Polish Cycling Federation regulations, cyclists are strictly forbidden to deviate from the lane they selected when launching into the sprint and, in so doing, endangering others. Furthermore, what is crucial, according to point 5.1 of Part II of the Polish Cycling Federation regulations, deviation from the chosen line that obstructs or endangers another cyclist or irregular sprint (including pulling the jersey or saddle of another cyclist, intimidation or threat, blow from the head, knee, elbow, shoulder, hand, etc.) constitutes a disciplinary offence for which, in serious cases, the commissaires' panel (jury) may disqualify a cyclist. 


\section{CONCLUSION}

To sum up, it will be extremely difficult to determine that the injuries suffered by cyclist Fabio Jakobsen in the crash at the finish of the first stage of the 77th Tour de Pologne were caused under the conditions of sport risk justification. Additionally, Dylan Groenewegen's behaviour has already been judged, although naturally not by the investigating authority. According to the commissaires' panel decision, Dylan Groenewegen was disqualified and excluded from further competition. However, the findings of the panel are not binding for the investigating authority. Nevertheless, it is difficult to imagine that the investigation authority will come to a completely different conclusion about the competitors' compliance with the sport rules during the finish of the first stage of the 77th Tour de Pologne than the commissaires' panel. These issues will probably also be subject to the opinion of a sports expert. In practice, in cases involving sports accidents, the body conducting criminal proceedings will allow a sports expert's opinion as evidence in order to assess the behaviour of competitors as well as competition organizers, through the prism of their compliance with sport rules, in particular the precautionary rules for the prevention of sport accidents. The sports expert should also express his opinion on the safety measures used by the race organizers, including metal barriers surrounding the race route. The need to comply with the precautionary rules to prevent sports accidents applies not only to the competitors themselves, but also to other people, including coaches, competition organizers and anyone whose behaviour may affect the safety and lack of danger to the health and life of the competitors, as well as bystanders, during sports competition [15].

\section{REFERENCES}

[1] Deryło M. Skrucha sprintera [Repentance of the sprinter]. Gazeta Wyborcza.8-7 August 2020:12. Polish.

[2] Leniarski R. Za faule nie do więzienia [There is no jail for foul play]. Gazeta Wyborcza. 17 August 2020:20. Polish.

[3] Act of 6 June 1997 - Criminal Code (unified text: Journal of Laws of 2020, item 1444).

[4] Wideo: Sebastian Szczęsny: Jakobsen przetransportowany do szpitala. Jest w śpiączce farmakologicznej [Footage: Sebastian Szczęsny: Jakobsen transported to hospital. He's in a pharmacological coma]. https://sport.tvp. pl/49283787/77-tour-de-pologne-fabio-jakobsen-w-stanie-spiaczki- farmakologicznej-przetransportowany-do-szpitalawideo. Polish.

[5] Todur W, Kaczmarczyk G. Tour de Pologne: niebezpieczna prędkość [Tour de Pologne: dangerous speed]. Gazeta Wyborcza.7 August 2020:4. Polish.

[6] Tumidalski W. Kiedy rywalizacja staje się przestępstwem [When rivalry becomes a crime]. Rzeczpospolita. 10 August 2020;184:11. Polish.

[7] Wolnicki K. Są dobre wieści [There is good news]. Przegląd Sportowy. 7 August 2020;184:2. Polish.

[8] Wolnicki K. Koszmar na finiszu [A nightmare at the finish]. Przegląd Sportowy. 6 August 2020;183:2. Polish.

[9] Todur W, Leniarski R. Fabio chce na rower [Fabio wants to bike]. Gazeta Wyborcza. dated 13 August 2020: 24. Polish.

[10] Offical site Tour de Pologne, Poważna kraksa na pierwszym etapie 77 Tour de Pologne [A serious crash on the first stage of the 77 tour de pologne] https://www.tourdepologne.pl/2020/08/powazna-kraksa-na-pierwszym-etapie-77tour-de-pologne/ Polish.

[11] Gardocki L. Prawo karne [The criminal law]. Warsaw;2017, 136-137. Polish.

[12] Młynarczyk-Puławska K. Ryzyko sportowe jako okoliczność wyłączająca bezprawność czynu w polskim prawie karnym [Sports risk as a circumstance excluding the unlawfulness of an act in Polish criminal law]. Lublin; 2018, 104-105. Polish.

[13] Decision of the Supreme Court of 7 January 2008, V KK 158/07, OSNKW 2008/5/34.

[14] Act of 25 June 2010 on sport (unified text: Journal of Laws of 2019, item 1468, as amended).

[15] Kubiak R. Legalność pierwotna ryzyka sportowego [Primary legality of sports risk]. Prokuratura i Prawo. 2006;12: 27-29. Polish

[16] Szwarc AJ. Karnoprawne funkcje reguł sportowych [Criminal law functions of sport rules]. Poznań; 1977, 80-81. Polish.

[17] Polski Związek Kolarski. Przepisy sportowe [Polish Cycling Federation. Sports regulations]. https://ks.pzkol. $\mathrm{pl} / 25$, przepisy-sportowe.html 